\title{
腎囊腫
}

\section{Cystic of the Kidney}

\section{渡辺哲男 Tetsuo WATANABE*}

\section{緒言}

腎臓には㛾々囊腫が形成される。その大さ， 位置，数も種々であり，又分類も多様である。 Braasch 及び Hendrick ${ }^{3)}$ は

（1）停滞囊腫或は炎症性囊腫

（2）単純性霬腫（単発性，多発性，多房性， 血性)

(3) 腎盂性囊腫

(4) 芳腎搵囊腫

（5）緊の病的変化に 続発する二次性靈腫（結 不, 副腎腫, 結核, 婜盐腎炎, 血腫, 胞 虫症)

(6) 囊胞腎

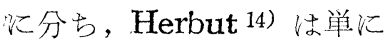

（1）囊胞腎

(2) 単純性露腫

（3）淋巴性囊腫

炕分つて特る。

この他多くの人々から実に多くの分類法が提 案されて怙るが，腎而性囊腫の如き囊胞様状態 及び炎症性疾患, 結石, 腫瘍, 寄生虫等原因の 明かなものから続発した二次性垔腫を除くと露 胞腎，孤立性腎囊腫の二種類に制約される。

尚この二者以外これらと相似た囊腫性疾患と 考光られるものに Funfack ${ }^{12)}$ のい 5 Hemmungsbildungen aus frühembryonalen Nierenanlagen そ Spence ${ }^{34)}$ のいう congenital unilateral multicystic kidney とがある.

Funfack の子のは腎の代りに腎臓部に囊腫 性構造物があり，その附近に尿管を欠いて物る。 囊腫間には非常に強く結合織が発育して招る。

* 朋天堂大学医学部泌尿器科教室 1957 年 5 月9 日受付
マルピギー氏体，曲細尿管及びヘンレ一氏係蹢 の如き正常終極腎原基毦属する組織 ず，血管茎無く血液の供給が悪い。

Funfack は極めて早期の胎生期汇於ける腎 原基の抑制的形成物（原腎遺残）或は畸形々乙 て执る. Spence のものは Funfack のものと 同様多数の豌豆大から鵎卵大の囊腫が葡菌の房 状に粗鬆な結合織によつて結合されて特り，腎 品，腎錐体，皮質もなく，正常の腎実質は見ら 机ない，又尿管はあつたとしても発育不全であ るか閉塞して扮る。以上 Funfack のものと全 く同じであるが Funfack のものと異る所は時 滘めて嚾少ながら実質性組織が見られ未発育 の細尿管及び系专体の棈造が 証明されることで ある。

以上の四型を考えてみるのに囊胞腎と孤立性 腎囊腫に於ては正常又は正常に近い腎実質が見 られ，後二者に於ては腎実質を思わしめるもの を全く欠くか，又存在することあるも極めて僅 少且つ未発育で，大部分は囊腫と之を邀結する 結合織より成るものである。

私は最近孤立性腎囊腫と囊胞腎との中間に位 するものと思われる症例 2 と囊胞腎 2 例を経験 したので之を報告し併せて両者の関係に就いて 考えてみたいと思う。

\section{自 験 例}

孤立性腎囊胞例

症例 150 歳 女 家婦

主訴 右季肋下部腫瘤

家族歴父系祖父母共に脳出血で死亡。田系 不詳. 父 68 歳腎疾患にて死亡. 田:42歳死亡死 因不詳. その他特に畸形及び遗伝的疾患は見ら れない。 
既往歴 18 才〜23才淋菌性尿道及び膀胱炎に 罹患した他に特記すべきことはない。

現病歴 昭和 29 年夏頃より歩行時右下腹部よ り右季肋下部にかけて笑き上げる様な軽い疼痛 があつたが，休止すれば軽快した。又この頃よ り右季肋下部に自分でる腫瘤を触れる様な気が した。これが次第に大いさを増して来る様に思 われた。約 1 年前から右季肋下部に膨満感があ り同部に手拳大の腫瘤を触れる様になり，同時 に腰痛を訴光る様になつた。この期間中病痛発 作はなかつた。上記の症状で当院に入院した。

入院時所見 体格栄養中等度, 肺肝界第 6 肋 刑, 腹部平垣, 静脈怒張認められず，右季肋下 部秒々膨隆し，ここに手拳大硬度硬き表面凹凸 不平，内側澎隆むる腫瘤を触れる。呼吸性移 動を認めない。下極は肋骨弓下約三横指下に山 り, 半坐位にて四横指下に達する。压痛はなく, 左腎は触れない。その他浮腫, 黄㾝, 発熱等は 認められない。

尿所見淡黄褐色透明, 酸性, 比重 1025, 蛋 白陰性, 赤血球 (一), 白血球 1 視野汇 2 3 万 上皮細胞僅少, 円柱 $(-)$, 細菌 (-)。

䏽胱鏡所見 可視粘膜正常.インジゴカルミ ン排泄は左右共に正常。

気後腹膜法と同時飞逆行性腎血撮影法を行 万、其の際採取した両腎尿には異常所見がない。

腎盂像 左腎は正常。右腎影像は下極は異常 なきも側方に於て異常の膨隆が認められる。又 腎素像は長軸方向に僅か飞延長し，且つ軽度の 円転異常がある。

上腎杯及下腎杯は内方に圧排延長せられ，従 つて中腎杯となす角度が增大して円味を帯びて 居るが，特に下腎杯の延長と内方転位が著しい。 か子る下婜杯像の外縁に沿つて上方に凹の孤を 描く院影が外方泟び，前述腎下極の腎影像を 越えてXII胁骨の先端附近まで追跡出来る。これ より上方は肝院影飞被われ，㹂上極と共に明ら かではない。

以上の所見より緊腄瘍又心孤立性腎垔胞が考 えられるが，腫樆大なるに比し，全身所罗良炊

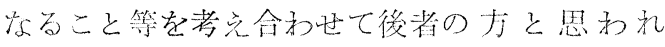

る。

その他の検查事項には特異なものはない。

手術所見 閉鎖式気管内麻酔の下に 経腹膜腎 摘出術施行.

摘出腎 重さ $450 \mathrm{~g}$ ，大いさ $14.5 \times 10.5 \times 10.5$

\section{$\mathrm{cm}$.}

肉眼的所見 前方中央飞 $9.5 \times 9.5 \times 9.5 \mathrm{~cm}$ 大 の囊胞が岕り，その表面全佮に半米粒大の囊胞 数十倜が散在する。内容は淡黄色透明漿液性の 液体 300cc であり，放置するにフイブリンの 折出をみた。

割面 腎実質内（主として皮質内涴豆大ま

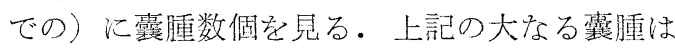
腎孟，腎杯とは交通を有しない。囊胞は囊壁に より数蔨の房に分たれている。即ち多房性であ る.

顕微鏡的所見 主要囊腫の壁は結合織より成 り，气の内面は単層の極めて扇平な上皮を以て 蔽われて和り，所によつては上皮細胞を欠いて おる。囊覑の隔壁には閉塞した動脈, 細尿管の 遺存せるものが見られる。又小露腫内面は空胞 を多く有する一層の著しく扁平化した上皮細 胞，内皮細胞樣に見光る細胞に蔽われておる。 囊腫に近く位置する腎実質に於ては糸正体は或 はボウマン氏孁が拡張せられてとの中にある係 蹢間に腔所々生じ，或は係䟹は萎縮してボウマ

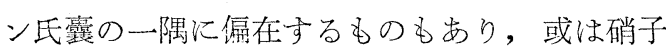
様変性の種々なる状態を示す。時にボウマン氏 囊内には係蹄失われ内容なきものが見られる。 又は係蹄の代りに蛋白様物質を見る。

多くの細尿管は拡張され，その腔内には蛋白 様物質を含むものがある。強く拡張せられた細 尿管に隣接与る細尿管は圧迫せられて扮る状態 を示して扮る。

尚皮質内には小露胞が形成せられ，細尿管に 囲繞せられて抢る。

腎盂には変化はない。

症例 279 歳 男

主訴血尿。

家族歴，境往歴共に特記すべさことはない。

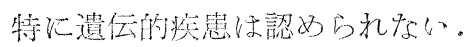


現病歴 約 10 ケ月前より時々血尿を認める他 は，何等自覚症状はない。

初診及び入院時所見 体格栄養中等度. 右側 季肋下に呼吸性移動性のある腎を触知出来る。 前立腺の硬度一様に稍々硬く, 大きさ稍大. そ の他外診上異常を認めない。

尿所見血尿, 酸性, 蛋白卅, 赤血球卅, 白 血球 + , 上皮細胞十, 細菌一。

膀胱鏡所見 膀胱頸部が隆起している他は可 視粘膜正常. 右側尿管口ょりの出血を認めた. インジゴカルミン排泄は, 右 3 分 30 秒, 左 4 分 5 秒にして出現, 共に濃青.

排泄性及び逆行性腎孟撮影法を施行, 左側は 腎及び腎孟像に異常を認めない。右腎影像の中 央に稍突出した膨隆を認め, 腎盂像内に小指頭 大の陰影を認めた。

左腎尿飞異常所見はない, 右腎尿, 蛋白十, 赤血球卅, 白血球僅少, 上皮細胞 + , 細菌一.

其の他検査事項. 腎機能, 濃縮試験, 1023, 1020，1035.フェノールフタレイン試験 2 時間 60\%．其の他17ーケトステロイド，血液酸フオ スフアターゼ, 血液像等は正常.

以上所見より右腎盂腫瘍の診断を下した。

手術，閉鎖循環麻酔の下に型の如く腎摘出術 を施行.

摘出腎 重さ $370 \mathrm{~g}$. 大さ $11.5 \times 6 \times 4 \mathrm{~cm}$.

術前診断の如く腎孟に小指頭大の乳頭状腫瘍 2 個を見たが，その他に積腫のあることを発見 した。

囊胞中前方中央のものは $6 \times 5 \times 4 \mathrm{~cm}$ の大さ を有し, 内容は漿液性である. 又後面稍中央に も小指頭大の囊胞がある。その他腎の表面には 半米粒大の囊胞が数十個散在して和る。囊胞は 腎線維性被膜によつて被われて扣る。

割面 腎実質内（主として皮質内）にも小指 頭大の囊胞数個を認め, 前記の囊胞は腎孟, 腎 杯とは交通を有せず，又隔壁により数個の房に 分たれて扮る。腎盂腫瘍は囊胞とは無関係であ つた。

顕微鏡的所見 囊腫の壁は結合織より成りそ の内面に極めて扁平な一層の上皮細胞が見られ
る.

糸求体はボウマン氏囊腔拡大せられて係蹄と の間に腔所があり，所により係蹄の菱縮と相俟 つて, この腔所の非常に広いものがある. 系㲑 体には時核增殖が見られ, 又硝子様变性に陥 つたものを見る。

細尿管は症例 1 亿比しては軽度ではあるが拡 張と圧迫とが証明される. 所により細尿管腔並 びにボウマン氏囊内に蛋白様物質が存在してお る.

\section{囊胞腎例}

症例 361 歳 女 家婦

主訴血尿, 口渴, 多尿, 高血圧。

家族歴 父 93 歳老衰飞て死亡, 四 62 才子宮 癌にて死亡. 兄弟姉妹 6 人, 長女及び末弟は健 康, 長男 57 歳肺炎, 次男 55 歳不詳, 次女 67 歳 肝臓癌, 四男細出血渚各々死亡. 子供 7 人, 次男及び長女共に当科に於て囊胞腎と診断され た。

既往歷 31 歳, 肋膜炎. 36 歳, 腹膜炎飞罹患 した。

現病歴 昭和 5 年腹膜炎に罹患し, 手術的治 療を受けた際に囊腫があることを注意された。 翌年多尿を訴光医師に右の腎臓が腫大している と云われた. 昭和 7 年泌尿器科専門医に腎霬胞 の診断を受けた。当時は口渴を訴える以外に自 覚症状はなかつた。その後 12〜13 年は別澛常 はなかつた。昭和 24 年頃には自分でる腹部の 腫瘤が容易飞触知出来た。昭和 27 年 3 月, 頭痛 及び多尿，特に夜間多尿を訴える様になつた。 又激しい動悸, 腹部膨満感, 食忿不振, 全身倦 怠等を訴えて, 当外来を訪れた。 3 月 27 日囊胞 腎の診断の下に入院し, 全経過中疼痛はなかつ た。昭和 27 年 3 月より昭和 31 年 3 月 1 日死亡 までに貧血を来し，輸血等のため入院せること 7 回を数える。

入院時所見 体格小, 栄養稍不良, 顔貌苦悶 状, 顔面蒼白貧血様, 眼結膜にも高度の貧血が 認められ, 黄誼はない。胸部臟器には異常なく, 肝は押し上げられ，肺肝界は右中鎖骨線でVI肋 骨位飞岕る。腹部恃全体に膨隆し，特に左右側 
腹部は緊張している，腹壁及び前胸部壁の静脈 は著明に緊張して副血行を見る。両側腹部に超 小児頭大の腫瘤があり，浮球感がある，表面は 粗大凹凸あり，硬く，呼吸性移動がある。右側 恃左側より大で, 腎下方限界は臍下三横指迄達 する。

尿所見 比重 1008 亿固定乙, 蛋白H , 赤血球 H，白血球僅少，腎上皮細胞，円柱を認めた。 尿量24 時間 $2000 \sim 3000 \sim 3500 \mathrm{cc}$.

膀胱鏡所見 可視粘膜正常.インジゴカルミ ン排泄は15 分間観察するも両側共排泄を見な w.

腎盂撮影像 経静脈性腎孟撮影によつては注 射後，10 分 20 分では共に 排泄は見られず，30 分に於て漸く薄い陰影を認めた。右腎孟はや〉 長軸方向えの延長を認め，尿管も外方より圧迫 せられている。左腎も同様，その他の像は詳ら かでない。逆行性腎盂撮影は患者により拒否さ れた。

その他の検査事項 赤血球数 $212 \times 10^{4}$. 輸血 により回復する，血圧最高 $200 \sim 230 \mathrm{mmHg}$, 最低 $90 \sim 162 \mathrm{mmHg}$ と漸次上昇を示した。血 中非蛋白窒素 $63.6 \mathrm{mg} / \mathrm{d} 1$ 昭和 28 年, $72.8 \mathrm{mg} /$ dl 昭和 29 年, $82.6 \mathrm{mg} / \mathrm{dl}$ 昭和 30 年, $140 \mathrm{mg} /$ dl 昭和 31 年と上梨を示した。

昭和 31 年鼻出血が持続し, 血圧 $230 \mathrm{mmHg}$, 血中非蛋白窒素 $140 \mathrm{mg} / \mathrm{dl}$ となり脳出血を併発 して 3 月 1 日死亡した。

剖検時腎の肉眼的所見 左腎 $1795 \mathrm{~g}, 25 \times 15$ $\times 8.5 \mathrm{~cm}$, 右腎 $1775 \mathrm{~g}, 23 \times 13.5 \times 10.5 \mathrm{~cm}$, 左腎 は右腎よりも大きく，表面は共に萄葡の戻状に 大小の囊胞を以て占められ，露胞は小は小豆大 以下ょり最大は手拳大に近いものがある，何れ も漿液或は茶赤色液を充満して, 緊張している。

割面 皮䯣の境界全くなく，大小の囊腫は腎 盂泊つて存し, 実質は僅かに肉柱状㳊存す るに過ぎない。特に右腎では実質は極めて少い。 大小の囊胞中には漿液性の液充満し，大なるも のは肉柱状で不完全な隔壁を有するものもあ る. 残在せる実質は特に周辺に多い，霬胞内壁 は平滑である，腎盂は左右共に拡張して露胞と
の交通は見られない。又充血，出血等も見られ ない、尿管は正常である。

顕微鏡的所見 症例第 4 例と同様の 变化を示 すも，腎実質の残存少なく，且つ变化の度も強 く系求体は萎縮して小となり，或は硝子様変性 飞陷り，或は气の内容失われ，正常に近いもの が殆どない，

細尿管はあるものは拡張し, あるものは圧迫 萎縮に陥り，或は退行変性に陥つて細胞は㴚濁 腫脹し，核の染度が弱い。

囊腫の壁は結合織よりなり，その内面に極め て扁平な一層の上皮細胞が見られる。所飞よつ ては上皮細胞を欠く。

症例 40 歳 男 会社員

主訴 左側腎部疼痛.

家族歷 特筆すべき事はなく，特に遺伝的疾 患はない。

現病歴 来院 2 週間前扁桃腺炎飞罹り，発熱 $38.5^{\circ} \mathrm{C}$ あり左腎部疼痛を訴光る様になつた。某 医より腎孟炎の診断を受け，治療を行つたが， 効果なく, 疼痛は去らず当科を訪れた。それま でに血尿, 腎部疼痛等はなかつた。

初診及び入院時所見 体格栄養共飞良好. 両 腎は季肋下に良く触知され，呼吸性移動がある。 その他外診上泌尿生殖器には变化を認めない。

尿所見 比重 1020 , 酸性, 蛋白士, 赤血球㘁 少，白血球僅少，上皮細胞僅少，細菌一。

膀胱鏡所見 可視粘膜正常.インジゴカルミ ン排泄は右側 6 分 54 秒にして出現 9 分 37 秒に して濃青となり，左側は 7 分 42 秒にして出現， 9 分 37 秒にして濃青となる.

気後腹膜法, 逆行性腎盂撮影法施行. 腎孟撮 影像は定型的なる腎䨳胞の像を示す。

フェノールフタレイン試験 $58.5 \%$ ，血圧 182 〜116 mmHg. その他検査事項に特記すべきこと はない。

手術, 左側腎を露出し, 囊胞の切開焼灼を行 い出来るだけ䨱胞を破壊した。

腎所見 大小種々の緊張せる無数の虂腫によ つて占められ，正常の腎実質見られず，その内 容によつて黄色, 黄褐色又は血性を呈して祘る。 


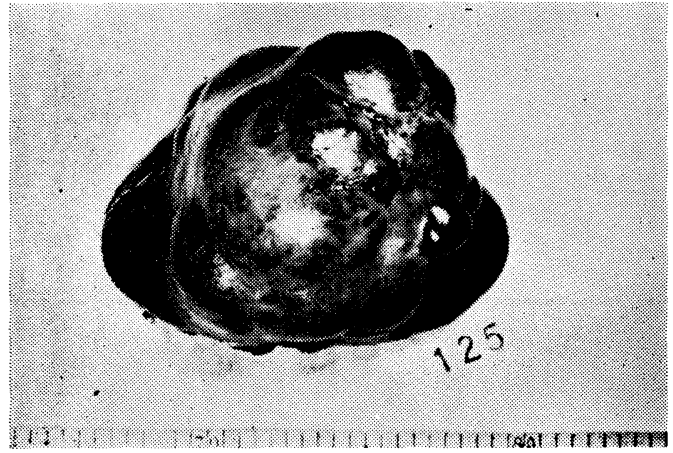

1. 第 1 例

外観

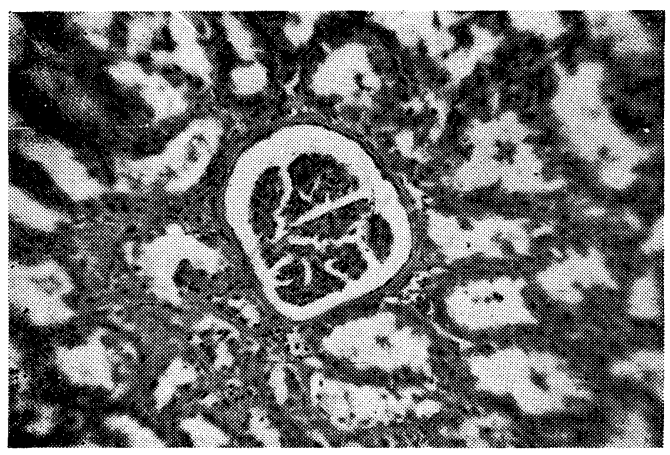

3. 第 1 例

ボウマン氏慗腔の拡張

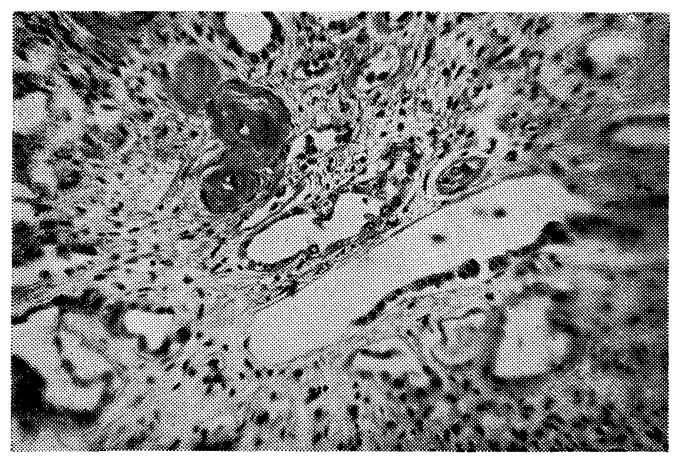

5. 第 1 例

細尿管の㹡張

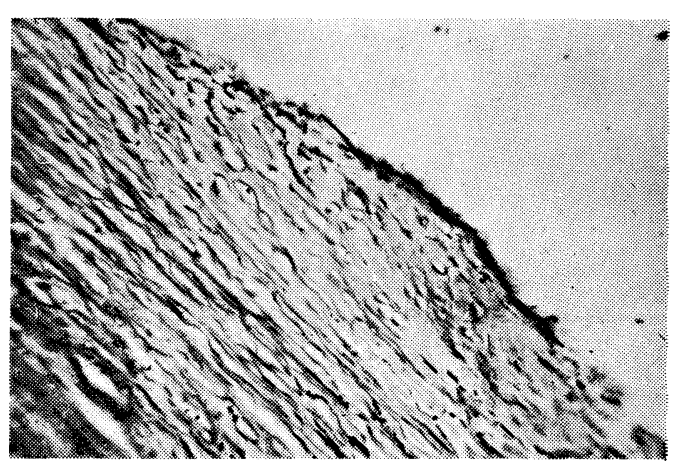

2. 第 1 例

囊腫壁の顕微鏡所見

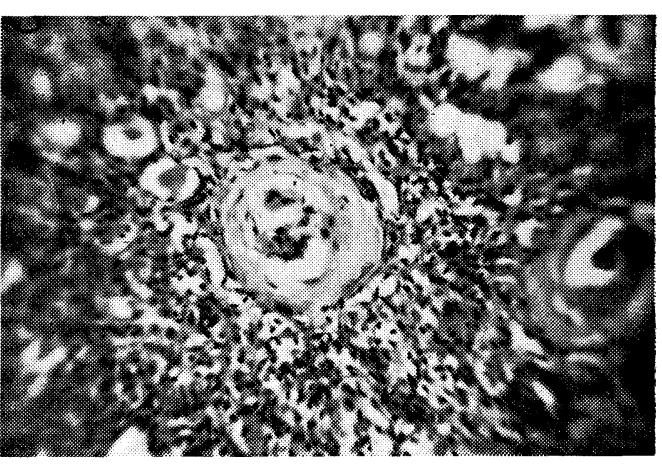

4. 第 1 例

糸球体の硝子様変性

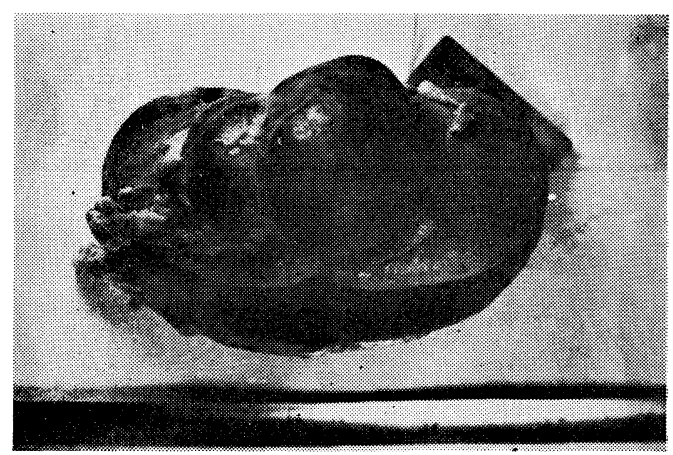

6. 第 2 例

外観 


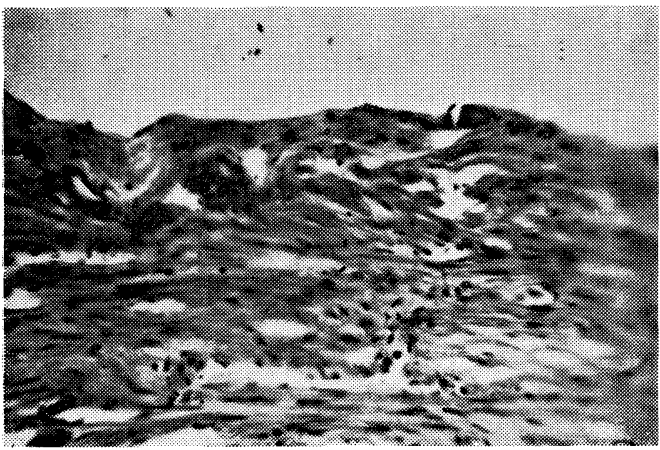

7. 第 2 例

蹾腫壁の顕微鏡所見

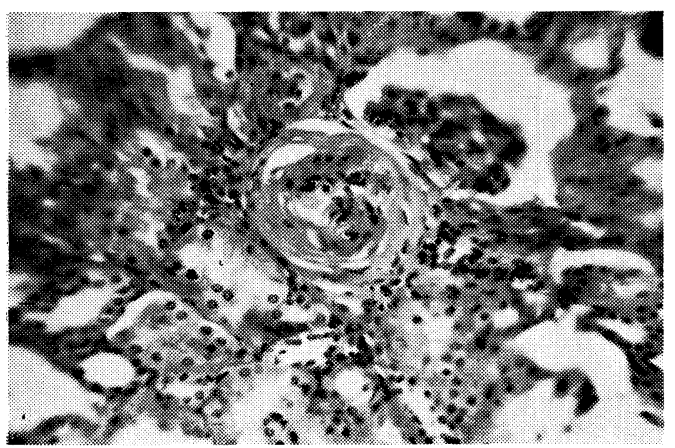

9. 第 2 例

糸求体の硝子様変性

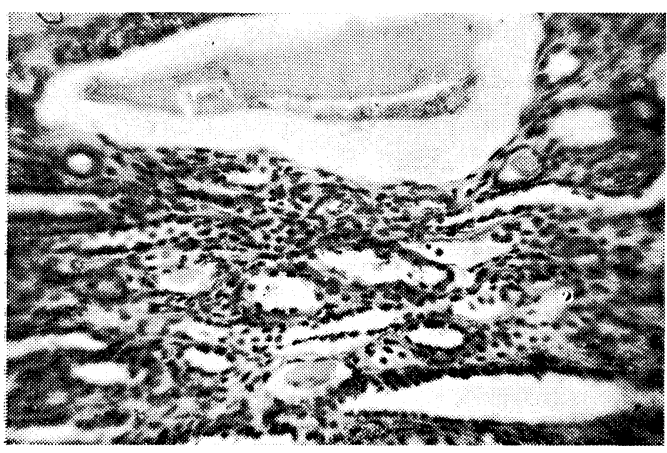

11. 第 2 例

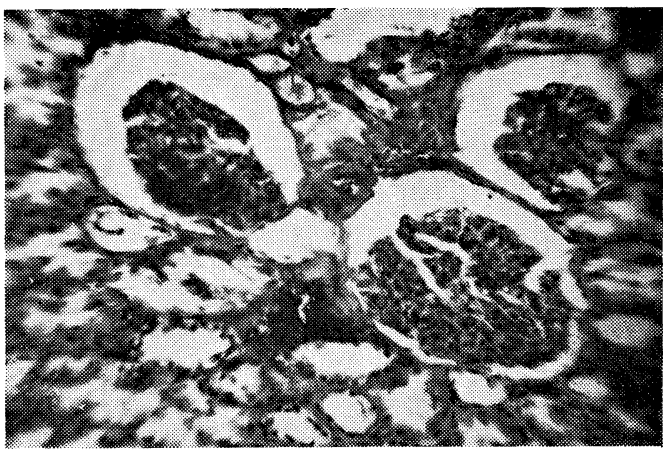

8. 第 2 例

ボウマン氏孁腔の拡張

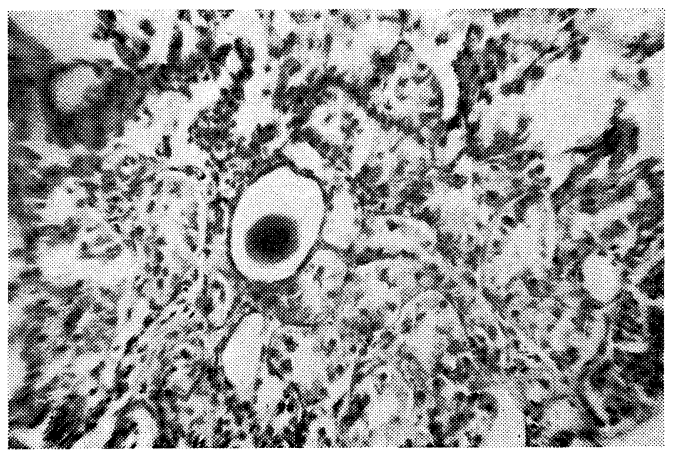

10. 第 2 例

糸球体係蹄消失蛋白様物質との置換

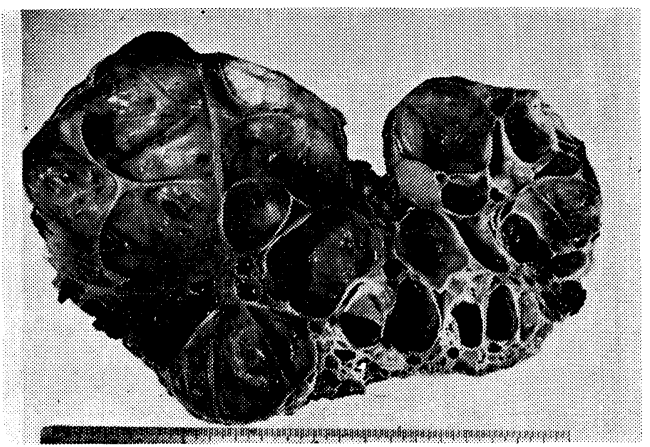

12. 第 3 例

切断面 


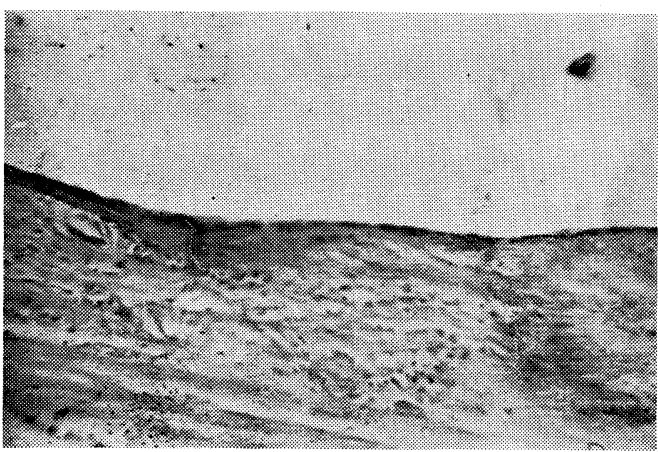

13. 第 4 例

䇾腫壁の顕微鏡的所見

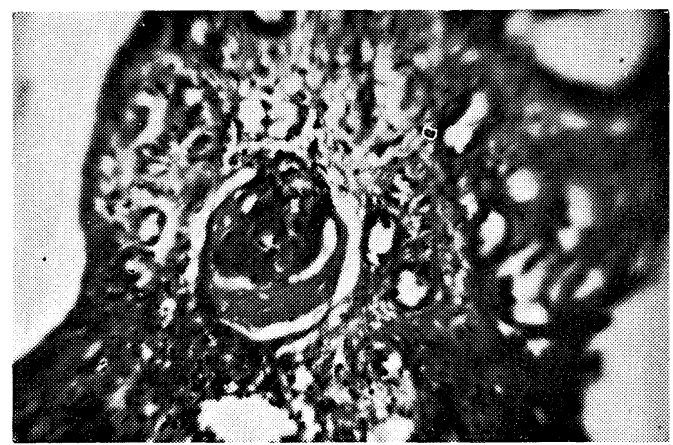

15. 第 4 例

米球体の硝子様変化

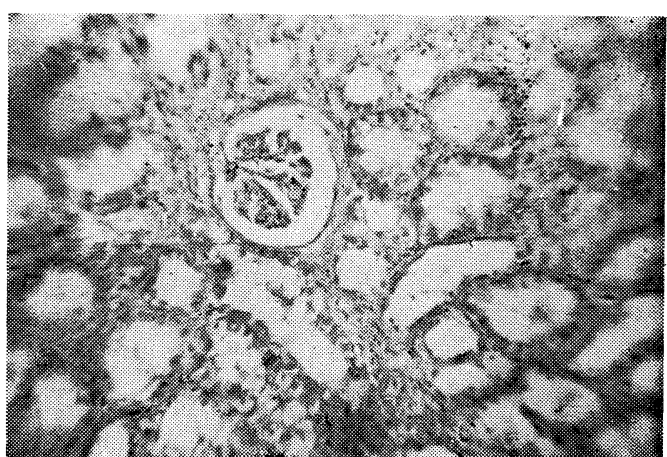

14. 第 4 例

ボウマン氏䙵腔の拡張

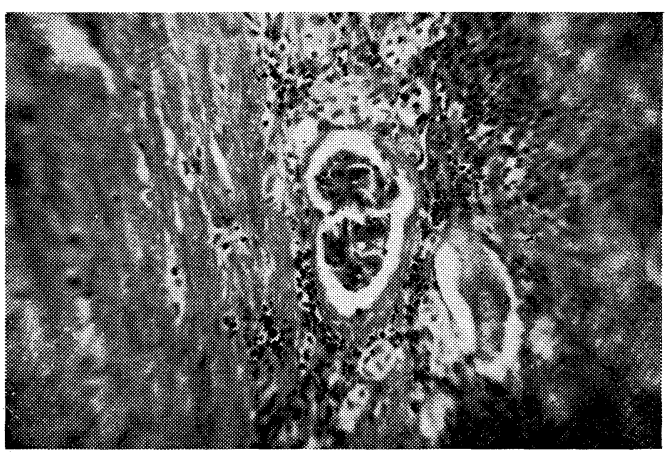

16. 第 4 例

糸球体の硝子様変化

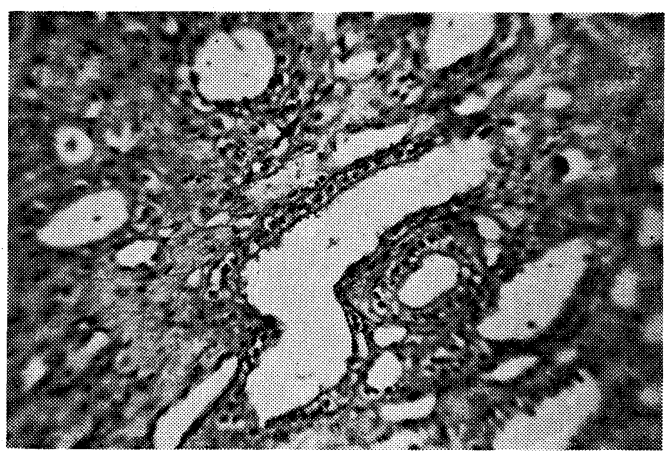

17. 第 4 例

細尿管の拡張 
これらの露胞を破るに深部に腎実質の僅かに残 存して抒るのを認める.

顕微鏡的所見 囊腫壁は結合織から成り，そ の内面は単層の極めて扁平な上皮細胞によつて 被われて招る，又囊腫比ては単層の骰子様 上皮細胞を見ることがあり，或は全く上皮細胞 を欠いて打るものもある。

これらの囊腫間には僅かながら腎実質を残し て扣る。残存せる腎実質に於ては系慦休は多く はボウマン氏囊が拡張せられて係蹢間に腔所を 生じて括る. 又同時に係蹄が萎縮して拡張した ボウマン氏囊の一隅に偏在し, 或は硝子様変性 に陥つて扔る。驿係蹄が全然消失してボウマン 氏囊腔の中は内容全く無く空所として見られる もの，係蹄が蛋白様物質と置換されて招るもの むある。

細尿管は部分的に拡張し上皮は扁平化してお り又上皮細胞の䟝脱して扣るものもある. 極め て少数ながら囊腫状に拡張して拈るものもあ る. 細尿管には又萎縮せるもの, 退行変性に陥 つて和るものがある。細尿管中には蛋白様物質 を含むものが比較的多く見られる。

\section{考按}

囊胞腎とは腎実質全般を無数の囊腫が占拠し て扣るものである。さして稀な疾患ではなく Bell 1) によれば, 22,393 剖検中 44 例にこれを 見て和る。家族的にも来り (Crawford 9) 恰 一家系 40 人中 17 人に之を証明した。私も自験

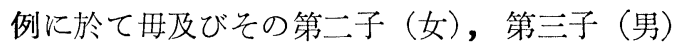
3 人に囊胞腎のあるものを見た。との他家族的 に見られた報告例は多数に上る)。両側を侵す のを常とするが又偏側のものもある（Bell によ れば 44 例中 40 例が両侧，4例が偏側であつた). 尚偏側の報告例も相当数見られる (Oppenheimer ${ }^{30)}$ 及び Narins ${ }^{31)}$, 堀内及び袷田 ${ }^{17)}$, 郭 19）等). 年令的には新生児より高令のものにま で見られるが Cannon 7) によれば40〜60歳間 に最も多いとして和る。多くの交献，成書によ つてもこれは一致して扣る。

Campbel1 6) によれば囊胞腎に二型が見られ
る.その一つは幼児, 若年者に又は死産児に認 められ，他の一つは思春期後或は成人となつて 後に現われ，腎の增大と機能低下を伴つて扔る。

孤立性腎囊腫は最近までこの名で呼ばれてい たが囊腫が単に一個に止まらないことも度々経 験されたことから，これを単純性腎腫と称する ことが多くなつて来た。

この疾患にあつては腎の種々なる場所に通例 1 個の大なる粘液性囊腫が 存在するのみである が，時によればこの他に大小種々な数佃乃至多 数の囊腫を伴つておることがあるものである. この疾患は囊胞腎に比し極めて稀であり, Guiterrez'3 は 1634 年より 1932 年までの文献から 315 例を集め得たのみであり，Is ael 18) は217 例の外科的腎疾患中 1 例を見たのみであり， Fish 11) によれば 11,879 の泌尿器科患者 $(4,011$ の腎疾患を含む) 中 32 例を証明し得たに過ぎな い。

年令はFish 11) によれば 19 歳より 72 歳まで, 平均 53 歳であつた。 Lowsley 及び Curtis ${ }^{26)}$ は 19 例を集め, 年令は 26 歳より 67 歳までぶ, 平均年令 50.2 歳であつた. Braasch 及び Hendrick ${ }^{3)}$ によれば 163 例の平均年令 49.8 歳であ り，その四分の三は五十年代より七十年代であ つた.

新生児, 幼児, 若年者に於けるものは極めて 少なく, Carson 8) によれば 153 例中 4 例が幼 児であり，Braasch 及び Hendrick ${ }^{3)}$ によれ ば 21 歳以下のものは 163 例中 4 例であり, De Weerd 及び S:mon 10) は 14 年間の文献を調 べ，幼年（生後 5 時間より 13 歳まで）に於ける もの漸く 16 例を蒐め得た。

本邦に於ては山田及び安富 ${ }^{37)}$ は文献より 44 例を集めたが，この中 20 歳以下のものは 6 例を 見たに過ぎない。

斯く幼児に於ては孤立性腎囊腫の䧄床上明白 なる大ささに達するものは極めて稀である。然 るに Campbel15) によれば幼児に於ても小なる 先天性の単純性腎囊腫は決して稀ではなく剖検 例では2〜4\%に於てこれを証明すると言つてお る。 
囊胞腎の発生原因に就ては種々の説があるが Ra11 及び Ode1 ${ }^{33)}$ は之を次の四に集約分類し て打る。

（1）新陳代謝説

Virchow ${ }^{38)}$ の意見である. 腎細尿管飞塩類 が沈澱し，ためにその閉塞を来たし，それより 中心部に分泌物の概滞を起すためである.

(2) 炎症説

Virchow が後に称えたもので，胎生児に於 浮烰炎の結果として来る ${ }^{24)}$.

(3) 腫瘍 説

Brigidi 及び Serveni ${ }^{4)}$ が最初に称えたもの で真性腫瘍であるとの説である。

(4) 発生上の欠陷説

Hildebrandt 16) が最初に考えた説で，集合管 と系正体部の胎生児淤ける癒合不全に原因寸 る抑制的畸形であるとの説である.Mutach ${ }^{29)}$ は集合管と系彗体部の結合以前に於敌る腎原基 の成長停止によるといい，Kampeier ${ }^{20)}$ は一定 の時期に退化すべき胎生期に於ける多数の囊腫 状腎小管が消失することなく反つてその成長を 続け，その結果として囊腫を生ずるとなした。 以上諸説の中現今に於ては発生上の欠陥による もの，殊飞分泌部と集合部との癒合不全による 抑制的畸形であると多くの人々から信ぜられて 扣る。

その根拋としては遺伝的関係 (家族的の出現) の証明せらるること (Crawforld ${ }^{9)}$ の例等), 他の臓器 (肝, 脾其の他骨, 卵巣, 副睪丸, 膵 等）飞囊腫が証明せられ，或は畸形（重複腎， 馬蹄腎, 腎の位置異常 15 , 重複尿管, 先天性 尿管拡張, 先天性尿管狭窄, 膀脱欠損, 膀胱憩 室, 尿管瘤, 尿道下裂, 停留睪丸, 重複子宮, 胵閉鎖, 直腸狭窄, 裂手 25), 裂足 ${ }^{25)}$, 陰性余 椎破裂 25) 等）の見られること, 組織学的検索 の結果炎症性変化なく又真性腫瘍たる確実な所 見子なく, 死産児, 乳児にも見られること等で ある。

以上述べたる如く囊胞腎が先天性の異常であ ることは肯定せられて稆るが，孤立性又は単純 性腎囊腫に於てはとの成因に就ての確説はな w.

囊胞腎及び孤立性腎囊腫の相違は囊腫の数及 びその大いさにあるが両者の間には移行型とも. 見らるべきものが存在する，私の 2 例も之に属 する。即ち 1 例に於ては 1 個の大なる囊腫があ り，これのみの存在ならば直ちに孤立性腎囊腫 と称せらるべきものであるがこの大なる囊腫以 外飞尚多数の小囊腫が存在しておらた。 又他の 1 例飞於ては囊胞腎としては囊腫の数は少な過 ぎるが囊腫の大さは囊胞腎に見らるるものより も遥かに大であつた。

孤立性腎囊腫は稀ではあるが胎児 (Fish 11)), 新生贤，幼児飞於ても見られ，充分なる大さに 達しないるのは剖検例によれは幼児の 2 4\%に 証明せられて招る(Campbel15)）。

孤立性腎囊腫に於ても亦同時に腎或は身体他 部に発育障碍を見ることがある。例光ば馬蹄鉄 腎 (Moynihan ${ }^{28)}$, Bockenheimer $\left.{ }^{2)}\right)$, 胎生性 分葉腎 $(\mathrm{Mc} \mathrm{Kim})$, 脳水腫, 指趾過多症, 内翻 足, 腹壁破裂 (Koster ${ }^{22)}$ ) 等が報告されて扔る. これより孤立性腎囊腫も亦発育障碍による畸形 なることを考劣しるる。

尚孤立性腎囊腫内容飞腎囊胞に於て屚々見ら れる硝子様円柱, 花冠状顆粒の証明世らるるこ とのある(小池 21$)$ ) のも囊胞腎ととの成因を同 じくすることを思わしめる。

私の例に於て組織学的検索を行つた結果, 囊 腫壁の組織所見は囊胞腎の囊腫壁の組織所見と 同様であり, 囊腫附近の腎組織の変化もその度 に強弱の差こそあれ 囊胞腎の所見と同様であつ た。

以上の諸点, 即ち胎児, 新生児, 幼児飞も見 られ，又同時に腎或は身体の他部に畸形を有す ることがあり先天性の起因を想定するも不可な く, 又䨳胞腎との移行型とも思われるものがめ りこの中間型に於ける組織的所見の囊胞腎の それと相似たる点から考光て孤立性腎囊腫も亦 囊胞腎と成因を同じくするものであり，唯分泌 部と集合部の癒合不全の度が量的に少ないもの では無からうかと推察するものである。 


\section{結語}

1. 私は単純性腎囊腫の 2 例及び囊胞腎 2 例 (1 例は剖検例， 1 例は手術例）に就て報告した。

2. 囊胞腎の成因は胎生時に於ける集合管と系 㲑体部との癒合不全に基く渏形であると考兄ら れて拉る。

3. 囊胞腎と孤立性腎囊腫の中間型と思わるる ものの所見等からして孤立性腎囊腫（単純性腎 囊腫）も亦囊胞腎ととの成因を等しくするもの で，癒合不全が量的に少ないるのであると思惟 せられる。

稿を終るに臨み，終始御郎切なる御指導御校閲 を賜つた小池正朝教授汇表心より感謝を捧げる。

\section{主 要 文 献}

1) Bell, E.T.: Ann. Int. Med., 27, 610, 1947. (cited by Herbut).

2) Bockenheimer, Ph.: Berl. klin. Wochenschr., 1641, 1911.

3) Braasch, W.F. and Hendrick, J.A.. J. Urol., 51, 1, 1944.

4) Brigidi and Serveni (cited by Herbut).

5) Campbell, M. : Clinical pediatric urology, 170, W.B. Saunders Co., Phila., 1951. (cited by De Weerd and Simon).

6) Campbell, M.F.: Urology, Vol. I, pp $255 \sim$ 266, W.B Saunders Co., phila. and London, 1954.

7) Cannon J.F.: Ann. Int. Med., 27, 610, 1947. (cited by Herbut).

8) Carson, W.J.: Ann. Surg., 87, 250, 1928. (cited by De Weerd and Simon).

9) Crawford, R.H.: Surg., Gynec. and Obst., 36, 185, 1923. (cited by Campbell).

10) De Weerd, J.H. and Simon. H.B.: J. Urol., 75, 912, 1956.

11) Fish, G.W.: J.A.M.A., 112, 514, 1939. (cited by Herbut).

12) Funfack, M.: Zsch. Urol., 49, 262, 1955.

13) Gutierrez, R.: Arch. Surg., 44, 279, 1942. (cited by Herbut).

14) Herbut, P.A.: Urological Pathology, Vol. I, pp 481 496, Lea and Febiger, Phila., 1952.

15) Herczeg, T., Rutkai, P. and Deák, J.: J. Urol., 76, 488, 1950.

16) Hildebrandt, A.: Arch. f. klin. Ch r., 48, 343, 1894. (cited by Campbel1).

17）堀内正元, 袴田八郎： 東京医事新誌，67,37, 1950.

18) Israel, J.: Chir. Klinik d. Nierenkrankheiten, Berl., 177 179, 1901.

19）郭敬心：日本臨林外科医誌，6,310, 1942.

20) Kampmeier, O.F.: Surg., Gynec. and Obst., 36, 208, 1923. (cited by Campbell).

21) Koike, M.: Mitteil. über allg. Path. u. path. Anat., 2, 557, 1926.

22) Koster, W.: Zit. nach Thompson.

23) Lich, R. Jr. and Wand, R.E.: J. Urol., 68, 60, 1952.

24) v. Lichtenberg, A., Voelcker, F. und Wildbolz, H.: Handb. d. Urol., Bd. III., SS 1 17, Julins Springer, Berlin, 1928.

25) Lorenz, G.: Zschr. Urol., 48, 653, 1955.

26) Lowsley, O.S and Curtis. M.S : J.A.M.A., 127. 1112, 1945. (cited by Herbut).

27) Mc Kim, G,F. and Simth, PG.: J. Urol., 635, 1924.

28) Moynihan, B.G.A.: Brit. med. J.. 263, 1902.

29) Mutach : (cited by Herbut).

30) Oppenheimer, G.D. and Narins, L.: J. Urol., 61, 86, 1949.

31) Norris, R.F. and Herrmann, L.: J. Urol., 46, 147, 1941.

32）大塚宏：皮泌誌，34，649，1933.

33) Rall, J.E. and Odel., H.M. . Am. J. Med. Sc., 218, 399, 1949. (cited by Campbel).

34) Spence, H.M.: J. Urol., 74, 693, 1955.

35) 高安久雄, 近藤賢：日泌会誌，46, 466, 1955.

36) Thompson, R.L.： Virchow's Arch., 188, 531 , 1907.

37) 山田栄吉, 安富祐：外科, 13, 185, 1951.

38) Virchow, R.: Arch. f. path. Anat., 45, 506, 1869. (cited by Campbell). 


\section{Summary}

1. Two cases of simple cysts of the kidney and two cases of polycystic disease of the kidney (one by necropsy and the other after operation) were reported.

2. The etiological factor of polycystic disease of the kidney is believed to be a hereditary disorder based on the failure of union of nephrons and collecting tubules during foetal stage.

3. From the findings indicating a transitional type between polycystic disease of the kidney, it is surmised that solitary cyst of the kidney (simple cysts of the kidney) with policystic disease of the kidney has a similar etiologic beginning and is a incomplete fusion of lesser degree.

Department of Urology, Juntendo University, School of Medicine. 